\title{
Application of Cycle 5E Learning Model in Photosynthesis Discussion to improve Skills of Science Processes Airmadidi State High School Students
}

\author{
Meity N Tanor ${ }^{1}$, Arrijani ${ }^{2}$, Debby J.J. Rayer ${ }^{3}$ \\ \{meitytanor@yahoo.co.id ${ }^{1}$ \} \\ Biology Study Program, Faculty of Mathematics and Natural Sciences, Manado State University1, 2,3
}

\begin{abstract}
This research is motivated by the learning conditions in Airmadidi State High School where there are weaknesses including: the learning process is still centered on the teacher as the main source of knowledge, where students do not dare to argue and some students do not pay attention to what is conveyed by the teacher. The objective to be achieved in this study is to improve student learning outcomes in photosynthesis material through the Learning Cycle learning model '5E' in class XII Science students at Airmadidi State High School in 2019/2020. This research is a classroom action research conducted at Airmadidi State High School with subjects of class XII science students. The object of research is the Learning Cycle ' $5 \mathrm{E}^{\prime}$ on photosynthesis material. The research process was carried out in two cycles which included five stages, namely planning, implementation, observation, reflection, and evaluation. The data analysis technique used is a qualitative descriptive technique that is by analyzing student development data in the first cycle and second cycle is equipped with an average analysis of cognitive values, affective values, and psychomotor values of students. The results obtained showed that the average student learning outcomes in the first cycle, cognitive domain = 71,67 affective behavioral domain (very good); and psychomotor domain (very interested). Average student learning outcomes in cycle II, cognitive domain $=80.15$ (successful) or increased from cycle I; affective domain (very good) or increased from the first cycle; psychomotor domain (very interested) or increase from cycle I. Based on the results of the study, it can be concluded that the Learning Cycle ' $5 \mathrm{E}$ ' learning model can improve the teaching and learning process, this is supported by an increase in Biology learning outcomes for students of class XII IPA SMA Negeri Airmadidi in the academic year 2019/2020.
\end{abstract}

Keywords: Learning Outcomes, Learning Cycle Learning Model '5e', Photosynthesis

\section{Introduction}

In the teaching and learning process there must be some weaknesses that affect student learning outcomes. The role of science, especially biology for future life is very strategic, especially in preparing future students who are critical, creative, competitive, able to solve problems and dare to make decisions quickly and accurately, so as to be able to survive productively amid the swift waves of global digital era competition full of opportunities and challenges. Learning is directed at creating an active, critical, analytical, and creative atmosphere in problem solving through the development of thinking skills.

Through strengthening partnerships between LPTK and laboratory schools or partner schools is a form of revitalization goals that have been implemented, in this case study programs 
that have been involved in the revitalization program have the potential to build and develop partnerships with partner parties both laboratory and school schools partners who have collaborated through the MOU. In this partnership program, LPTK lecturers will be assigned to laboratory schools or partner schools to work together to improve forms of reinforcement on the quality of learning.

From the observation results it is known that the biology learning process of class XII IPA of Airmadidi High School in the academic year 2019/2020 found weaknesses, namely: 1) students pay less attention to the teacher's explanation in each learning, 2) The teacher creates an unpleasant learning atmosphere, 3) Lack of awareness students in biology learning. In this case the teacher is required to be more creative in preparing the learning to be developed, besides that the teacher must be clever in choosing the type of learning model that is relevant to the material to be delivered. This certainly will affect the motivation of students to study more diligently so as to obtain high learning outcomes.

Classroom Action Research (CAR) is an action research whose root problems emerge in the classroom and are felt directly by the teacher concerned so that it is difficult to justify if there is an assumption that problems in Classroom Action Research arise from engineering researchers, therefore it is necessary to have evidence from the school so that the results Classroom Action Research that has been carried out is not a research engineer. In Classroom Action Research, researchers or teachers can see for themselves the practice of learning or with other teachers doing research on students in terms of aspects of their interactions in the learning process. The teacher can reflectively analyze and synthesize what has been done in class.

The main purpose of Classroom Action Research is to solve real problems that occur in the classroom. This research activity is essentially the Class Action Research aims to improve various real and practical problems in improving the quality of learning in the classroom experienced directly in the interaction between the teacher and students who are learning.

Learning model is a plan or a pattern that is used as a guide in planning learning in class or learning in tutorials and to determine learning tools including books, films, computers, curriculum, etc. Ramadhani states that each learning model directs us into designing learning to help students in such a way that learning objectives are achieved.

One innovative learning model that is able to facilitate students in constructing their own knowledge is learning by using the $5 \mathrm{E}$ learning cycle learning model (5E learning cycle). The '5E' Learning Cycle is a learning center that is student centered. The '5E' Learning Cycle is a series of activity phases organized in such a way that students can master the development of cognitive aspects which include: structure, content, and function. Intellectual structures are high-level mental organizations that individuals have to solve problems. Content is the typical behavior of individuals in responding to the problems faced, while the function is a process of intellectual development that includes adaptation and organization. The strengths of the '5E' Learning Cycle learning model are: a) Increase learning motivation because learners are actively involved in the learning process, b) Help develop learner's scientific attitudes, c) Learning becomes more meaningful .In addition to the above advantages why researchers use '5E' Learning Cycle learning model because this learning model is student centered which is a series of stages of activities organized in such a way that students can master the competencies that must be achieved in learning by playing an active role.

Based on this background, the researchers tried to conduct research in the form of classroom action research with the title of this research is "The Application of Learning Cycle Learning Model" 5E "to Improve Biological Learning Outcomes of Photosynthesis Material in Class XII Natural Sciences Airmadidi State High School 2019/2020. 


\section{Methods}

This research is a classroom action research that is practical, situational and conditional based on problems that arise in daily learning activities at school. This research is collaborative based, so this research collaborates with teachers in the field of biology studies who always strive to obtain optimal results. Through effective methods and procedures, so as to enable repetitive actions to improve student biology learning outcomes. Based on the planning that has been made by the researcher as well as the teacher doing the action of learning according to the plan of action made. The results of this study are expected to produce effective biology learning so that optimal results are obtained. Researchers always work closely with Biology study teachers, starting from: 1. Initial dialogue, 2. Action planning, 3. Implementation of actions, 4. Monitoring (Observation), 5. Contemplation (Reflection) on every action taken, and 6 . Evaluation.

This study refers to the Classroom Action Research model which can be briefly defined as one form of research that is reflective on the grounds of taking certain actions in order to improve the quality of the learning process in the classroom. Analysis of the data used in this study is descriptive qualitative, namely by analyzing student development data from cycle I to the last cycle, in this study researchers will analyze data from cycle I to cycle II using the flow method. In Classroom Action Research with descriptive qualitative data analyzed since the learning action is carried out, developed until data acquisition through data processing. The technique used is flow media, which consists of three activities, namely data reduction, data presentation, and drawing conclusions.

For data obtained from cycle I to cycle II is processed quantitatively, by comparing the average student learning outcomes from cycle I which are then compared with the average learning outcomes of students from cycle II. An increase in the average results of the first cycle compared to the second cycle showed an increase in the learning outcomes of students of class XII IPA Airmadidi High School on photosynthesis through the learning model Leaning Cycle '5E'. Thus the steps of qualitative data analysis in this action research were carried out since the action was carried out. To find out the activities and student learning outcomes in learning, drawing conclusions is done by looking at the success of students who get an average value above 75 or greater equal to 75 . If the student activity increases each cycle, then student learning outcomes also increase.

\section{Results and Discussion}

The results of the research results obtained are displayed in the following forms:

Table 1. Results of analysis of cognitive aspects of the Early Cycle to Cycle II students of Class XII IPA Airmadidi High School with the application of the Learning Cycle learning model 5E'.

\begin{tabular}{llll}
\hline Information & $\begin{array}{l}\text { Initial } \\
\text { value }\end{array}$ & Cycle I & Cycle II \\
\hline $\begin{array}{l}\text { The maximum } \\
\text { value }\end{array}$ & 100 & 100 & 100 \\
\hline
\end{tabular}




\begin{tabular}{|c|c|c|c|}
\hline Information & $\begin{array}{l}\text { Initial } \\
\text { value }\end{array}$ & Cycle I & Cycle II \\
\hline $\begin{array}{l}\text { A minimum } \\
\text { value }\end{array}$ & 15 & 56 & 64 \\
\hline The average & 50.91 & 71.67 & 80.15 \\
\hline $\begin{array}{l}\text { The number of } \\
\text { students who } \\
\text { scored more } \\
\text { than KKM ( } 75)\end{array}$ & $\begin{array}{l}14 \\
(40 \%)\end{array}$ & $\begin{array}{l}26 \\
(74.3 \%)\end{array}$ & $32(91.42 \%)$ \\
\hline
\end{tabular}

Table 2. The results of the analysis of the affective aspects of cycle I through Cycle II students of Class VII Natural Sciences Airmadidi High School with the application of the Learning Cycle learning model ' $5 \mathrm{E}$ '.

\begin{tabular}{llcc}
\hline No & $\begin{array}{l}\text { Indicator } \\
\text { assessment }\end{array}$ & Cycle I & Cycle II \\
\hline 1 & $\begin{array}{l}\text { Paying } \\
\text { attention }\end{array}$ & $68.89 \%$ & $87.16 \%$ \\
2 & $\begin{array}{l}\text { Discipline of } \\
\text { time and } \\
\text { attendance } \\
\text { Activity in } \\
\text { cooperation } \\
\text { Bringing } \\
\text { textbooks }\end{array}$ & $78.74 \%$ & $98.02 \%$ \\
\hline
\end{tabular}

Table 3. The results of the analysis of the psychomotor aspects of cycle I to Cycle II of Class XII Science students at Airmadidi State High School with the application of the Learning Cycle learning model '5E'.

\begin{tabular}{llcl}
\hline No & $\begin{array}{l}\text { Indicator } \\
\text { Assessment }\end{array}$ & Cycle I & Cycle II \\
\hline 1 & $\begin{array}{l}\text { Assembling } \\
\text { tools and }\end{array}$ & $58.19 \%$ & $96.16 \%$ \\
& materials & & \\
2 & Using tools & $71.63 \%$ & $96.16 \%$ \\
3 & Using & $72.63 \%$ & $95.16 \%$ \\
& ingredients & & \\
4 & Getting to & $83.15 \%$ & $95.16 \%$ \\
& know tools & & \\
& $\begin{array}{l}\text { and } \\
\text { materials }\end{array}$ & & \\
\hline
\end{tabular}




\section{Discussion}

According to Wijaya, states that the criteria for national standard schools generally have good teacher staff and educational facilities, and have good achievements, and specifically that schools have adequate facilities to improve the quality of learning, plus extracurricular activities, have clean classrooms, laboratories, offices, bathrooms, clean, orderly, shady and safe school environment [1]. In terms of the quality of teaching staff being able to show enthusiasm in teaching and working, student UAN results show an increasing tendency, and schools have programs improving the professional performance of teachers and other education personnel. From the criteria of good schools above, Airmadidi State High School is included in the National Standard School (SSN).

In the application of the learning model Learning Cycle '5E' obtained student learning outcomes in cognitive, affective, and psychomotor aspects. The average results and the percentage of completeness of each cycle in each aspect increases, this is influenced by various factors both internal and external factors. The '5E' Learning Cycle learning model provides an opportunity for each to be more active, creative, and bolder in opinion because this learning model is student centered. The advantage of the '5E' Learning Cycle learning model is to increase learning motivation because learners are actively involved in the learning process, help develop learner's scientific attitudes, learning becomes more meaningful because students can easily follow the teaching and learning process. There are several cycles that are applied to solve and answer problems that occur in the classroom from the initial observations. In each cycle that is applied, each uses the Learning Cycle learning model '5E' in the ongoing teaching and learning activities. To find out the changes in the process caused by the research, the evaluation is done by evaluating students from cognitive, affective, and psychomotor assessments.

The results of the analysis of cognitive aspects in the first cycle are still low and unsatisfactory. The average grade of 71.67 there were 26 students who completed with a percentage of completeness reaching $74.3 \%$ and there were 8 students who had not completed with a percentage of $22.86 \%$. The researcher wants to know the extent to which the application of the '5E Learning Cycle' learning model can improve student learning outcomes. Because cognitive aspects of learning outcomes in cycle I are still low, it is necessary to make improvements in cycle II so that student learning outcomes can be improved. These improvements include 1) Optimizing the learning model. 2) Provide maximum motivation for students to be active in learning. 3) Maximum use of facilities and infrastructure in the laboratory. 4) there is interaction, and communication that is more relaxed between the teacher and students in learning so that students will feel comfortable and not tense in following learning in class. In the evaluation obtained an average of learning outcomes on the cognitive value of the second cycle 80.15 or an increase of 8.48 from the first cycle (71.67) or an increase of 20.76 from the initial value (50.91). The cognitive aspects of learning outcomes in cycle II showed an increase compared to cycle I. The results of the percentage of completeness in the cycle II reached $91.42 \%$. The increase in results was influenced by several factors, both internal and external factors. The possibility of internal factors that can cause student learning outcomes is still low, among others: student interest is still lacking in biology subjects because they consider biology subjects boring, memorized and personal students do not like biology. While external factors include: the condition of the room that is not neat, the learning model used is not understood by students, the lack of interaction between teachers and students and the lack of motivation both motivation from teachers and families. This is in line with Sudjana (2005: 3940) which states the learning outcomes achieved by students are influenced by two main factors namely factors within the students themselves and factors that come from outside themselves or 
environmental factors consisting of teachers, programs, facilities and infrastructure, instruments and curriculum. The results of the analysis of affective aspects, consisting of four parameters, namely attention, discipline of time and attendance, activeness in working together, carrying textbooks. The results obtained in cycle I, and II have increased. The results for each parameter on the ability of students to pay attention to the percentage of completeness only reached $68.89 \%$, in this case students were not focused or were still indifferent in learning activities. The ability of students in time discipline and attendance is very good the percentage of completeness reaches $100 \%$, because students are familiar with the rules applied by the teacher, where in participating in learning activities students must be disciplined in time, students must follow the learning activities well. The ability of students to be active in working with the percentage of completeness reaches only $78.74 \%$, in this case students are not focused or are still indifferent in learning activities, and the ability of students in carrying textbooks completeness reaches $80.6 \%$, this is because students are accustomed with the rules applied by the teacher, where in participating in learning activities students must prepare everything related to the lesson to be delivered and students must follow the learning activities well. The results obtained in the first cycle in the affective aspects are still low then the next cycle is carried out, but there are some notes that must be considered in the implementation of the second cycle including students still need a lot of guidance, motivation and optimization of learning models, because the teacher's role also influences learning outcomes by giving motivations and rewards so students are more active and confident, and there is more relaxed interaction and communication between teacher and students in learning so that students will feel comfortable in participating in class activities. The learning outcomes in the second cycle in the affective aspect increased, each completeness parameter reached $96.16 \%$ of students able to work very well, had no hesitation in asking and answering questions from both the teacher and other students. Students begin to be motivated and interested in learning because the use of tools and materials is very good and the use of learning models that are more optimal. The results of the analysis of psychomotor aspects, consisting of four parameters, namely the ability of students to assemble tools and materials, use tools, use materials, recognize tools and materials. The results obtained in cycle I, and II increase. The results for each parameter on the ability of students to assemble tools and materials the percentage of completeness only reached $58.19 \%$, in this case the media presented were still unclear and the use of time was not effective so that it affected the results of stringing students in psychomotor asepek. The ability of students to use the percentage of completeness tools only reaches $71.63 \%$, where students are still less skilled at arranging tools in the learning process, the ability of students to use the percentage of completeness only reaches $72.63 \%$, in this case students have not been able to place the material correctly in learning activities, and students' ability to recognize tools and materials the percentage of completeness reaches $83.15 \%$ in this case students are already familiar with the tools and materials of photosynthesis practicum in learning activities. The results obtained in the first cycle in psychomotor aspects are still less than perfect, then the next cycle is carried out, but before the implementation of the second cycle there are some notes that must be considered including: 1) Students still need a lot of guidance, more motivation so students can be more open and brave in opinion and answering questions, 2) More optimization in the application of learning models, 3) There is a more relaxed interaction and communication between the teacher and students in learning so that students will feel comfortable in participating in class activities. The results obtained in the second cycle are better than the first cycle in the affective aspects, cognitive aspects, and psychomotor improved, it is seen that almost all students are ready to take biology lessons, students take an active role in learning biology, in addition students have a better understanding of the material presented so class learning is more fun. During the learning process there is a two-way 
communication between the teacher and students, and learning is centered on the student so that the student becomes a student subject. Learning cycle II there are improvements both in cognitive, affective and psychomotor, because during learning takes place, communication between the teacher and students is well established, the courage of students in asking questions, answering questions, expressing ideas, learning takes place smoothly, students are interested in the way the teacher conveys material, and student learning outcomes increase from initial observation until the second cycle. Overall evaluation of the implementation of the actions in cycle II, is that learning in cycle II creates more student activity in the KBM, by applying the learning model '5E' Learning Cycle will foster a pleasant learning atmosphere because this '5E' Learning Cycle learning is preferred by students, so that encourages students to study harder. This is proven by improving the quality of learning outcomes in terms of cognitive, affective, and psychomotor, especially in the subject matter of photosynthesis. From the results of the first cycle and second cycle research there are other advantages of the Learning Cycle learning model '5E' which can be used to determine the extent of students' understanding of the learning material given by the teacher beforehand. Students who have not mastered the material that has been taught will certainly have difficulty in finding answers. Assessment of affective and psychomotor behavior is to use a questionnaire filled out by the teacher during the learning process. This questionnaire contains the responses from students regarding the learning model 'Cycle of Learning' 5E 'which is applied in learning. Furthermore, for cognitive assessment obtained after students work on Posttest. When viewed from the cognitive, affective, and psychomotor values individually from cycle I to cycle II, the results are obtained that with the Learning Cycle learning model '5E' activities and student learning outcomes from cycle I to cycle II increase. The increase in results was influenced by several factors, both internal and external factors. The possibility of internal factors that can cause student learning outcomes is still low, among others: student interest is still lacking in biology subjects because they consider biology subjects boring, memorized and personal students do not like biology. While external factors include: the condition of the room that is not neat, the use of facilities and infrastructure that are not optimal in learning, learning strategies and media used are not understood by students, lack of interaction between teacher and students and lack of motivation both motivation from teachers and families. In addition there are internal and external factors that affect student learning outcomes in cognitive aspects to be increased among them namely: physiological conditions of students who are in good condition, and optimizing models and instructional media so that students are more enthusiastic and happy in participating in learning while helping students understand the material presented. The use of this learning model in photosynthesis material makes students who have been unwilling to engage in learning actively participate in learning. Every student is motivated to be able to issue opinions, ideas or ideas according to his own sentence. The teacher is only a student facilitator so that this learning can be used to train student creativity and improve learning outcomes. Through learning '5E' Learning Cycle, can measure the extent of students' understanding of the material that has been learned. The advantages of this learning model include: a). Increase learning motivation because learners are actively involved in the learning process; b). Help develop the scientific attitude of the learner; c). Learners become more meaningful because the learning model Learning Cycle '5E' is student centered which is a series of stages of activities organized in such a way that students can master the competencies that must be achieved in learning by playing an active role. The results obtained in the second cycle are better than the first cycle in the affective aspects, cognitive and psychomotor aspects improved, seen in almost all students ready to take biology lessons. Students take an active role in learning biology, besides that students have a better understanding of the material presented so that learning is more enjoyable. During the 
learning process there is a two-way communication between the teacher and students, and learning is centered on the student so that the student becomes a student subject. The application of the '5E' Learning Cycle learning model can improve student learning outcomes, this is in line with the results of Farida's research, stating that the application of the '5E' Learning Cycle model to improve the learning outcomes of high school students in physics learning, based on the results of his research, the average student learning outcomes in the cognitive, affective, and psychomotor domains have increased in each learning series [2]. It is also in line with the results of Destyanti's research, stating that the application of the '5E Learning Cycle' model to improve student learning outcomes in physics learning [3]. Based on the results of his research it was found that student learning outcomes for the cognitive and psychomotor domains had increased. In learning by applying the Learning Cycle ' $5 \mathrm{E}$ ' learning model, it can overcome the problems faced in learning biology, including the lack of student activity in the process learning, students are less motivated and interested in learning biology because of the delivery of monotonous material using lecture methods, material that is abstract and tends to be considered difficult, students' understanding is still lacking about biology subject matter which impacts on student learning outcomes are low. This can be proven by an increase in student learning outcomes in cognitive, affective, and psychomotor aspects. Thus it can be concluded that the Learning Cycle '5E' learning model can improve student learning outcomes and can be used as an evaluation to determine the extent of student understanding of the material that has been learned, so it is evident that the '5E' Learning Cycle learning model can improve student learning outcomes in class XII IPA Airmadidi State High School in the academic year 2019/2020 on photosynthesis. With the Learning Cycle learning model ' $5 E^{\prime}$ ' students can be actively involved in learning and be able to express ideas or ideas, be able to ask questions and respond to questions towards other students so that the atmosphere of learning activities is more lively and enjoyable.

\section{Conclussion and Suggestions}

\section{Conclusion}

Based on overall data analysis both cognitive, affective and psychomotor values, it can be concluded that: There is an increase in student learning outcomes by applying the Learning Cycle Learning Model '5E' to Improve Biological Learning Outcomes of Photosynthesis Material in Class XII Natural Sciences Airmadidi Academic Year 2019 / 2020

Suggestion

The next researcher is expected to look for other material that is suitable with the learning cycle of '5E' Learning and is expected to obtain affective data for initial observation should use a questionnaire, so that it can really be known directly the number of students who have problems in learning because the researchers have not use a questionnaire during initial observation. The school should pay attention to facilities and infrastructure, especially learning media so that it can be used to support a better learning process.

\section{References}

[1] Wijaya.: SSN School Criteria (National Standard Schools), Available: http://adifia.wordpress.com/2009/07/28/k Criteria-School-ssn. (2009) 
[2] Farida., Rida, H.: Implementation of Type 5E Learning Cycle Learning Model to improve High School Student Learning Outcomes in Physics Learning, Bandung: Thesis at UPI FMIPA, Available: http://repository.upi.edu/operator / upload / s_d0251_0605514_bibliograph y.pdf (2010)

[3] Destyanti, Dewi.: the application of the Learning Cycle $5 \mathrm{E}$ model to improve student learning outcomes in physics learning, Jakarta: Journal, Indonesian Education University, Available: http://repository.upi.edu/operator/upload/s_pgsd_0701210_chapter2.pdf (2010) 